\title{
TRADE SPECIAL ISSUE: FOREWORD
}

\author{
Meredith Kolsky Lewis*
}

This issue of the Victoria University of Wellington Law Review focuses on trade law, featuring four articles addressing trade issues from diverse angles. The first three articles identify problems or constraints in current international trade rules (relating to the World Trade Organization (WTO) in the first instance and to potential free trade agreement obligations in the second and third instances) and the negative consequences that countries could experience as a result of these flaws. In contrast, the fourth article identifies positive aspects of other international trade rules, namely those pertaining to the United Nations Convention on Contracts for the International Sale of Goods 1980 (CISG), and explains how there could be beneficial domestic effects to applying the CISG rules more broadly.

In the first article, Oliver Delvos addresses the complex issue of how fisheries subsidies should best be regulated. Subsidies in the fisheries sector lead to over-fishing and thus contribute to the depletion of international fish stocks. Delvos argues that the current WTO rules governing subsidies do not appropriately capture the problem of subsidies in the fisheries sector, both because certain subsidies that should be prohibited are currently allowed and because other subsidies that should be permitted are currently technically prohibited. Delvos asserts that therefore new rules are needed, potentially through amending the Agreement on Safeguards and Countervailing Measures (SCM Agreement), to better reflect the particular problems relating to fisheries subsidies.

The second and third articles were originally presented as papers at the Australia New Zealand Society of International Law (ANZSIL) Annual Symposium "Free Trade Agreements: Boon or Bane for Australasia?"1 The symposium examined the role of free trade agreements (FTAs) in Australasia, highlighting positives and negatives associated with the proliferation of FTAs in the region generally, as well as concerns relating to particular features of specific agreements. Presenters included academics, government officials, and members of the business community. In her paper, Jane Kelsey critically examines the relationship of Pacific islands countries with Australia and New Zealand pursuant to the Pacific Agreement on Closer Economic Relations (PACER). She

* Lecturer, Faculty of Law, Victoria University of Wellington.

1 Victoria University of Wellington, Faculty of Law, 28 August 2005. 
explains that although Pacific island nations have numerous reservations regarding the wisdom of entering into free trade negotiations with Australia and New Zealand, their commitments under PACER and the Pacific Plan may leave them with little choice. Kelsey argues that Pacific governments need the policy space to adopt economic strategies consistent with their development needs. However, free trade arrangements with Australia and New Zealand would severely constrain these countries' policy options and would risk further de-stabilising the region.

Thomas Faunce, Kellie Johnston and Hilary Bambrick's article, which Dr Faunce presented at the ANZSIL symposium, examines the implications of the Australia-United States Free Trade Agreement (AUSFTA) for the Australia New Zealand Therapeutic Products Authority (ANZTPA). In particular, the article identifies obligations the Australian Therapeutic Goods Administration (TGA) has incurred pursuant to the AUSFTA, and cautions that these obligations may now be "inherited" by the ANZTPA, an agency Australia and New Zealand have agreed in principle to create to replace the Australian TGA and the New Zealand Medicines and Medical Devices Safety Authority. The article identifies eight major areas in which New Zealand's regulation of medicines and medical devices could be affected, including through potential "evergreening" obligations to notify patent holders of applications for approval to market generic drugs and the possible need to impose intellectual property protections in excess of those required under the WTO's Agreement on Trade Related Aspects of Intellectual Property Rights (TRIPS).

Finally, Nicholas Whittington examines whether New Zealand should extend its application of the United Nations Convention on Contracts for the International Sale of Goods 1980 (CISG) beyond international transactions to additionally apply to domestic sale of goods transactions. In particular, Whittington advocates repealing the remedial provisions of the Sale of Goods Act 1908 and replacing those provisions with new rules based on the provisions of the CISG. In support of this position, Whittington argues that the CISG rules on avoidance of a contract provide more certainty and a more just outcome than does current New Zealand law relating to the termination of sale of goods contracts. Furthermore, harmonising New Zealand's rules such that a uniform law applies to both international and domestic sale of goods contracts would suit New Zealand's domestic trade dynamics and would reduce legal costs to New Zealand's importers and exporters. Such a move would not be unprecedented, as other countries such as the People's Republic of China and Germany have elected to adopt the CISG's rules in both the international and domestic contexts.

This collection of articles reflects the significant impact international trade rules and obligations can have on domestic governments and economies. If "all politics is local", 2 so perhaps is all trade law. Trade, whether of the domestic or international variety, has ripple effects that touch us all.

2 See generally Thomas P O'Neill and Gary Hymel All Politics is Local (New York Times Books, New York, 1994). 